\title{
Seasonal variation in apparent conductivity and soil salinity at two Narragansett Bay, RI salt marshes
}

\author{
Richard McKinney ${ }^{\text {Corresp., } 1}{ }^{,}$Alana Hanson ${ }^{1}$, Roxanne Johnson ${ }^{1}$, Michael Charpentier ${ }^{2}$ \\ ${ }^{1}$ Atlantic Ecology Division, US Environmental Protection Agency, Narragansett, Rhode Island, United States \\ ${ }^{2}$ General Dynamics Information Technology, Narragansett, Rhode Island, United States \\ Corresponding Author: Richard McKinney \\ Email address: Mckinney.Rick@epa.gov
}

Measurement of the apparent conductivity of salt marsh sediments using electromagnetic induction (EMI) is a rapid alternative to traditional methods of salinity determination that can be used to map soil salinity across a marsh surface. Soil salinity measures can provide information about marsh processes, since salinity is important in determining the structure and function of tidally influenced marsh communities. While EMI has been shown to accurately reflect salinity to a specified depth, more information is needed on the potential for spatial and temporal variability in apparent conductivity measures that may impact the interpretation of salinity data. In this study we mapped soil salinity at two salt marshes in the Narragansett Bay, RI estuary monthly over the course of several years to examine spatial and temporal trends in marsh salinity. Mean monthly calculated salinity was $25.8 \pm$ 5.5 pt at Narrow River marsh (NAR), located near the mouth of the Bay, and $17.7 \pm 5.3$ ppt at Passeonkquis marsh (PAS) located in the upper Bay. Salinity varied seasonally with both marshes, showing the lowest values (16.3 and 8.3 ppt, respectively) in April and highest values (35.4 and 26.2 ppt, respectively) in August. Contour plots of calculated salinities showed that while the mean whole-marsh calculated salinity at both sites changed over time, within-marsh patterns of higher versus lower salinity were maintained at NAR but changed over time at PAS. Calculated salinity was significantly negatively correlated with elevation at NAR during a sub-set of 12 sample events, but not at PAS. Best-supported linear regression models for both sites included one-month and 6-month cumulative rainfall, and tide state as potential factors driving observed changes in calculated salinity. Mapping apparent conductivity of salt marsh sediments may be useful both identifying within-marsh micro-habitats, and documenting marsh-wide changes in salinity over time. 


\section{Seasonal variation in apparent conductivity and soil} 3 salinity at two Narragansett Bay, RI salt marshes 4

Richard A. McKinney ${ }^{1}$, Alana R. Hanson ${ }^{1}$, Roxanne L. Johnson ${ }^{1}$, Michael A. Charpentier ${ }^{2}$

${ }^{1}$ US Environmental Protection Agency, Atlantic Ecology Division, Narragansett, RI USA

${ }^{2}$ General Dynamics Information Technology, Narragansett, RI USA

Corresponding Author:

Richard A. McKinney

US EPA, 27 Tarzwell Drive, Narragansett, RI 02882 USA

Email address: mckinney.rick@epa.gov 
Abstract

\section{Background}

19

Measurement of the apparent conductivity of salt marsh sediments using electromagnetic induction (EMI) is a rapid alternative to traditional methods of salinity determination that can be used to map soil salinity across a marsh surface. Soil salinity measures can provide information about marsh processes, since salinity is important in determining the structure and function of tidally influenced marsh communities. While EMI has been shown to accurately reflect salinity to a specified depth, more information is needed on the potential for spatial and temporal variability in apparent conductivity measures that may impact the interpretation of salinity data.

\section{Methods}

We used EMI to map soil salinity at two salt marshes in the Narragansett Bay, RI estuary monthly over the course of several years to examine spatial and temporal trends in marsh salinity. A portable conductivity meter was used to generate apparent conductivity values along randomly-oriented transects across the marsh surface, which were then calibrated with traditional porewater salinity measures taken at a randomly selected sub-set of sample points and converted to salinity values. Data were stored in a shapefile and subsequently used to create contour maps of salinity across the marsh surface.

\section{Results}

Mean monthly calculated salinity was $25.8 \pm 5.5$ ppt at Narrow River marsh (NAR), located near the mouth of the Bay, and 17.7 $\pm 5.3 \mathrm{ppt}$ at Passeonkquis marsh (PAS) located in the upper Bay. Salinity varied seasonally with both marshes, showing the lowest values (16.3 and $8.3 \mathrm{ppt}$, respectively) in April and highest values (35.4 and $26.2 \mathrm{ppt}$, respectively) in August. Contour plots of calculated salinities showed that while the mean whole-marsh calculated salinity at both 
40 sites changed over time, within-marsh patterns of higher versus lower salinity were maintained at

41 NAR but changed over time at PAS. Calculated salinity was significantly negatively correlated

42 with elevation at NAR during a sub-set of 12 sample events, but not at PAS. Best-supported

43 linear regression models for both sites included one-month and 6-month cumulative rainfall, and

44 tide state as potential factors driving observed changes in calculated salinity. Mapping apparent

45 conductivity of salt marsh sediments may be useful both identifying within-marsh micro-

46 habitats, and documenting marsh-wide changes in salinity over time.

\section{Introduction}

48 Salt marshes are productive ecosystems that by nature of their position in the landscape are

49 subject to many natural and anthropogenic stressors. In the Northeast US there is concern about

50 the impact of accelerated sea level rise on salt marsh hydrology (e.g., Watson et al. 2017), and

51 how changes in marsh flooding might impact vegetation community structure (Smith et al.

52 2017). Changes in vegetation communities may impact ecosystem services provided by salt

53 marshes, and hence may have implications for their conservation and role in coastal - -

54 ecosystems. For example, plant community structure can influence belowground biomass

55 accumulation, which in northeastern US salt marshes is an important mechanism for marsh

56 accretion that can mitigate the effects of sea-level rise (Bricker-Urso et al. 1989, Turner et al.

57 2000). Alteration of vegetation community structure may also impact the provision of other

58 ecosystem services such as nutrient storage, habitat availability for fauna, and fisheries

59 production (Kelleway et al. 2017).

60 Tidal inundation is an important determinant of salt marsh vegetation community structure,

61 realized in part through the species-specific differences in physiological responses of plants to

62 salinity. As sea level rises the extent of tidal inundation will increase, potentially altering the

63 distribution of plant species across a marsh. Since increased inundation will alter soil porewater 
64 salinity, and the primary route of water uptake in salt marsh plants is through porewater (e.g., Al

65 Hassan et al. 2017), measurement of soil porewater salinity could provide insight into potential

66 vegetation community changes resulting from sea-level rise (Silvestri and Marani 2004).

67 However, few studies have examined whole-marsh porewater salinity, in part because of the

68 labor-intensive sampling required and the difficulty in consistently obtaining porewater samples

69 at depth. An alternative is to estimate salt marsh porewater salinity by measuring the apparent

70 conductivity $\left(\mathrm{EC}_{\mathrm{a}}\right)$ of salt marsh sediments using electromagnetic induction, which can generate

71 sufficient data over the course of several hours to map soil salinity across a marsh surface. This

72 approach provides estimates of soil salinity even in areas where the saturated zone is deep, or

73 where there are clay or fine sediment layers with low hydraulic conductivity rendering porewater

74 difficult to sample.

75 Measurement of $\mathrm{EC}_{\mathrm{a}}$ in soils has been used since the mid-20 $0^{\text {th }}$ century to aid in mineral and

76 petroleum exploration and extraction, and over the past 40 years to characterize the salinity of

77 agricultural soils (DeJong et al. 1979). More recently the emergence of portable instrumentation

78 capable of rapid field measurements has allowed for its use in the estimation of other soil

79 parameters (Robinson et al. 2004). In simplest terms, at a given temperature $\mathrm{EC}_{\mathrm{a}}$ is primarily

80 influenced by four characteristics: soil composition, i.e, mineral or clay content; bulk density;

81 moisture content; and ion concentrations, which can be representative of soil salinity (Corwin

82 and Lesch 2005). Each of these characteristics affects the bulk conductivity of soils, which in

83 turn influences the extent to which an induced electromagnetic field can be generated through the

84 soil. $\mathrm{EC}_{\mathrm{a}}$ is determined by measuring this induced electromagnetic field, which in turn reflects

85 the average conductivity, influenced by all soil characteristics, over a volume of soil (Doolittle et

86 al. 2001). Differences in instrument response can be experimentally calibrated to changes in a 
87 selected soil characteristic, allowing, under the assumption that all other characteristics are

88 constant, for a proxy measure of changes in that characteristic in the soil.

89 Application of $\mathrm{EC}_{\mathrm{a}}$ measures in salt marshes to map soil porewater salinity was first explored in

90 the early 2000s (Paine et al. 2004) but later developed by Moore et al. (2011). The approach

91 uses an electromagnetic induction (EMI) instrument to measure $\mathrm{EC}_{\mathrm{a}}$ at a series of sample points

92 across a marsh surface. At a subset of sample points, $\mathrm{EC}_{\mathrm{a}}$ is calibrated with soil porewater

93 salinity, measured using a sipper technique (Portnoy and Valiela 1997). The resulting calibration

94 curve is then used to calculate salinity based solely on $\mathrm{EC}_{\mathrm{a}}$, which can then be mapped in a GIS

95 to develop contours of salinity values across the marsh surface. This technique has been used to

96 examine the relationship between plant species distribution and soil salinity during the growing

97 season, but to our knowledge no earlier studies have looked at inter-annual changes in soil

98 salinity patterns. In this study, we measured $\mathrm{EC}_{\mathrm{a}}$ across two southern New England salt marshes

99 along an estuarine salinity gradient over a period of 2 years to investigate intra-marsh variability

100 in soil salinity, as well as potential drivers of seasonal changes in mean salinity observed at each

101 marsh. The underlying assumption of this technique is that in uniformly saturated soils, such as

102 those found in salt marshes, the contribution of soil moisture content to $\mathrm{EC}_{\mathrm{a}}$ will be constant, and

103 that variability contributed by other soil characteristics is limited, such that changes in $\mathrm{EC}_{\mathrm{a}}$

104 values will accurately reflect changes in porewater salinity. To begin to evaluate the validity of

105 this assumption, we also examined changes in the relationship of $\mathrm{EC}_{\mathrm{a}}$ and measured porewater

106 salinity at our sites with respect to potentially confounding factors such as bulk density, percent

107 moisture of the soil, and marsh elevation. Our results will provide information about the

108 magnitude of seasonal salinity change observed at a marsh, as well as identify potential drivers

109 of that change. Our study will also aid in evaluating $\mathrm{EC}_{\mathrm{a}}$ as a surrogate for porewater salinity, 
110 provide insight into potential factors influencing $\mathrm{EC}_{\mathrm{a}}$ in salt marsh soils, and help identify

111 environmental factors that could confound the relationship between $\mathrm{EC}_{\mathrm{a}}$ and salinity. This

112 information may allow for more widespread application of the technique, for example to use in

113 monitoring the trajectory of marsh degradation or recovery during salt marsh restoration efforts.

\section{Materials \& Methods}

115

116

\section{Site Descriptions}

117 The study area was two salt marshes sites located in the Narragansett Bay estuary, Rhode Island,

118 USA (Figure 1). The southern site (NAR) was near the mouth of the Pettaquamscutt sub-estuary $119\left(41^{\circ} 26^{\prime} 49.6^{\prime \prime} \mathrm{N}, 71^{\circ} 26^{\prime} 58.0^{\prime \prime} \mathrm{W}\right)$, and had a total area of $5.89 \mathrm{ha}$. The upland edge of the site 120 was bordered by an equal proportion of private residences and forest habitat. The marsh surface

121 consisted of low marsh habitat dominated by short form Spartina alterniflora, and high marsh

122 habitat dominated by Spartina patens, Distichlis spicata, and Juncus gerardii. The high marsh 123 upland border consisted primarily of Iva frutescens, and small patches of Typha spp. and 124 Schoenoplectus spp. The northern site (PAS) was within the Passeonkquis Cove sub-estuary $\left(41^{\circ}\right.$ $\left.12544^{\prime} 52.8^{\prime \prime} \mathrm{N}, 71^{\circ} 23^{\prime} 5.2^{\prime \prime} \mathrm{W}\right)$, and had a total area of $2.35 \mathrm{ha}$. The upland edge of the site was 126 bordered by an approximately $100 \mathrm{~m}$-wide patch of trees and dense understory vegetation, 127 transitioning to dense residential land use. The marsh surface consisted of low marsh habitat 128 dominated by tall form Spartina alterniflora, and high marsh habitat dominated by Spartina 129 patens and Distichlis spicata. The high marsh - upland border consisted primarily of Iva 130 frutescens, with a 0.68 ha patch of Typha spp. at the northern edge of the border.

131 Field Measurements

132 A Geonics Model EM38-MK 2 Conductivity Meter (Geonics Ltd, Mississauga, Ontario, Canada) 133 was used in horizontal mode, held $50 \mathrm{~cm}$ over the marsh surface, to record $\mathrm{EC}_{\mathrm{a}}$ readings. The 
134 readings were the result of an induced current generated by the instrument through a maximum

135 penetration depth of approximately $1.0 \mathrm{~m}$ of soil at randomly distributed sample points across

136 each marsh surface. $\mathrm{EC}_{\mathrm{a}}$ values in milliSeimans meter ${ }^{-1}\left(\mathrm{mS} \mathrm{m}^{-1}\right)$ along with the latitude and

137 longitude of the sample point and vegetation characteristics were entered into an ArcGIS

138 shapefile using ArcPad software (ESRI, Redlands, CA) on a Trimble Nomad hand-held field

139 computer (Trimble Navigation Ltd., Sunnyvale, CA USA). Samples were taken approximately

140 every 30 days beginning October, 2015 through October 2017 ( $n=24$ sample events). Both sites

141 were surveyed on the same day at approximate 10:00 am (NAR site) and 12:00 pm (PAS site).

142 The surveys consisted of a random transect pattern walked across the marsh surface, with $\mathrm{EC}_{\mathrm{a}}$

143 values, vegetation characteristics, and sample point position recorded approximately every $5 \mathrm{~m}$.

144 Porewater salinity measures were taken at a randomly selected sub-set of sample points (mean

145 frequency of $29.6 \%$ of the points across both marshes) using a sipper consisting of a $0.5 \mathrm{~m}$ long

146 piece of $1.0 \mathrm{~mm}$ diameter serrated metal tubing inserted in the soil to a depth of $0.25 \mathrm{~m}$. Once

147 inserted, approximately $25 \mathrm{ml}$ of porewater was withdrawn and its salinity measured using a

148 refractometer. Porewater salinity readings, when taken, were also stored in the ArcGIS

149 shapefile.

150 Following field sampling, shapefiles were transferred to a GIS where contour maps of calculated

151 salinity across each marsh surface were created using the ArcGIS version 10.3 Spatial Data

152 Analyst, inverse distance-weighted interpolation function (ESRI, Redlands, CA). EC $\mathrm{C}_{\mathrm{a}}$ data were

153 first converted to calculated salinity values using marsh and survey-specific calibration curves

154 constructed from a least-squares regression of $\mathrm{EC}_{\mathrm{a}}$ values and measured porewater salinities.

155 Calculated salinity values were then used in the ArcGIS software inverse distance-weighted

156 interpolation function to create marsh-specific contour maps for each sample event. 
157 Elevation values were collected using an RTK GPS Global Navigation Satellite System (GNSS)

158 receiver (Trimble Navigation Limited, Dayton, Ohio) at approximately 100 locations per marsh.

159 Each sample location was selected at approximately $5 \mathrm{~m}$ intervals along randomly-placed

160 transects across the marsh surface. Elevations were referenced to nearby benchmarks, and the

161 WGS84 ellipsoid model was used to determine vertical and horizontal position. The National

162 Geodetic Survey Geoid 12A (CONUS) model was used to calculate elevations from orthometric 163 heights (North American Vertical Datum of 1988 [NAVD88]), and all points were projected to

164 North American Datum of 1983 (NAD83) Universal Transverse Mercator zone 19. Digital

165 elevation models (DEMs) were created from survey points using the inverse distance weighting

166 function in ArcGIS software. Elevation values corresponding to sample point locations were

167 interpolated from the DEMs for 12 sample events corresponding to maxima and minima values

168 of mean whole-marsh calculated salinity. Three sample events were chosen to bracket each of

169 two occurrences of maxima and minima over the course of the study. Interpolated elevations

170 ranged from $0.24-0.76 \mathrm{~m}$ above mean sea level (MSL) for NAR, and from $0.49-1.04 \mathrm{ft}$ above

171 MSL for PAS. We estimated bulk density and moisture content of soil by collecting 6 soil cores

172 of $25 \mathrm{~cm}$ depth along a randomly-placed transect from the upland to seaward edge at each site.

173 Two cores were collected at the mid-point of the high and low marsh zones as determined by

174 dominant plant species, and at the mid-point of the transect (mid marsh). Each core was

175 sectioned in $5 \mathrm{~cm}$ increments and a soil subsample from each depth was weighed, dried, and then

176 re-weighed to determine bulk density and percent moisture. Permission for this non-invasive

177 field study was provided by RI Department of Environmental Management, under collection

178 permits \#2015-31-F - 2018-31-F. 
179 Total rainfall was obtained from the NOAA National Centers for Environmental Information,

180 Climate Data Online website (https://www.ncdc.noaa.gov/cdo-web/) for the stations Kingston,

181 RI $\left(41^{\circ} 29^{\prime} 25.1^{\prime \prime} \mathrm{N}, 7^{\circ} 32^{\prime} 34.8^{\prime \prime} \mathrm{W}\right)$, located approximately 9 km northwest of NAR, and

182 Providence, RI ( $\left.41^{\circ} 50^{\prime} 33.7^{\prime \prime} \mathrm{N}, 7^{\circ} 23^{\prime} 6.7^{\prime \prime} \mathrm{W}\right)$, located approximately $10.5 \mathrm{~km}$ north of PAS.

183 Daily rainfall amounts were aggregated into cumulative amounts over $24 \mathrm{hr}, 36 \mathrm{hr}, 1 \mathrm{month}, 3$

184 month, and 6 month periods prior to each sample event. Using Spearman Rank Correlation

185 analysis we found that $24 \mathrm{hr}$ and $36 \mathrm{hr}$ values were significantly correlated $\left(\mathrm{r}^{2}=0.88, \mathrm{p}=0.001\right)$,

186 as were 1 month and 3 month cumulative values $\left(r^{2}=0.45, p=0.001\right)$. We therefore included

187 only $24 \mathrm{hr}, 1$ month, and 6 month cumulative rainfall in linear regression models to examine the

188 effect of cumulative rainfall and tide height on mean calculated salinity. Tide heights were

189 obtained using online tide charts containing the time of low and high tides and corresponding

190 tide heights relative to mean low water (NOAA Tides and Currents,

191 https://tidesandcurrents.noaa.gov/). We used data from sites at Narragansett Pier, RI $\left(41^{\circ} 25^{\prime}\right.$

$\left.19256.0^{\prime \prime} \mathrm{N}, 71^{\circ} 27^{\prime} 25.2^{\prime \prime} \mathrm{W}\right)$ located approximately $2 \mathrm{~km}$ south of NAR, and Pawtuxet Cove, RI (41

193 44' 53.6"N, 71²3' 0.6"W) located approximately $1.3 \mathrm{~km}$ north of PAS. Tide height was

194 extrapolated at time of sampling from predicted tide ranges and expressed as a proportion of the

195 maximum tide height for the tide cycle during which the sample occurred.

\section{Data analysis}

197 We examined temporal variability in calculated salinity for each marsh by plotting mean

198 calculated salinity versus sample date. Calculated salinities were derived from $\mathrm{EC}_{\mathrm{a}}$ data that

199 were converted to calculated salinity values using marsh and survey-specific calibration curves

200 constructed from a least-squares regression of $\mathrm{EC}_{\mathrm{a}}$ values and measured porewater salinities at

201 points where sipper measurements were taken. The slopes of the calibration curves ranged from

$2020.018-0.081$ (mean $0.044 \pm 0.016)$ at NAR, and from $-0.099-0.144($ mean $0.054 \pm 0.016)$ at 
203 PAS. Coefficients of determination ranged from $0.12-0.92$ (mean $0.49 \pm 0.19$ ) at NAR, and 204 from $0.01-0.84$ (mean $0.40 \pm 0.22$ ) at PAS.

205 The effect of cumulative rainfall and tide height on mean calculated salinity in the marsh was 206 examined by constructing a series of linear regression models and evaluating the models using 207 small sample Akaike Information Criteria $\left(\mathrm{AIC}_{\mathrm{c}}\right)$, which accounts for biases that might arise 208 from relatively small sample size (Burnham and Anderson 2002). Candidate linear regression 209 models $(\mathrm{n}=15)$ were ranked by computing $\mathrm{AIC}_{\mathrm{c}}$ differences or Akaike weights as $\Delta \mathrm{AIC}_{\mathrm{c}}=$ $210 \mathrm{AIC}_{\mathrm{c} i}-\mathrm{AIC}_{\mathrm{cmin}}$ (Burnham and Anderson, 2002, pp. 70-72). We then selected models best 211 supported by the data as having $\Delta \mathrm{AIC}_{\mathrm{c}}$ values between 0.00 and 2.00 (Burnham and Anderson 212 2002, pp. 75-77), and calculated the relative importance $(w+(j))$ of each parameter by summing 213 the Akaike weights of all models that included this characteristic (Burnham and Anderson 2002, 214 pp. 167-169). Relative importance values provide a means to incorporate selection uncertainty in 215 the evaluation of a set of parameters, and larger values of $w+(j)$ indicate whether a parameter 216 may be a better predictor variable (Burnham and Anderson 2002). Statistical analyses were 217 performed with SAS for Windows ver. 9.41 (SAS Institute, Inc., Cary, NC, USA).

218 We examined intra-marsh spatial and temporal variability in calculated salinity by plotting 219 calculated salinity versus elevation at the sample points. We used least-squares regression of 220 calculated salinity and corresponding elevation values obtained using the DEM for a given marsh 221 and sample event for a sub-set of 12 sampling events chosen to correspond with maxima and 222 minima in mean salinity values observed over time. We then compared regression statistics to 223 trends in overall mean salinity for each marsh over time.

\section{Results}

225 For the NAR marsh, salinity was high at the seaward edge and low at the terrestrial border across 226 the spring to fall growing season (Figure 2). For PAS, contour plots show a more uniform 
227 distribution of salinity values across the marsh surface, particularly at calculated salinity minima

228 (Figure 3). During the October 2017 calculated salinity maximum, there was some evidence of a 229 pattern of lower salinity towards the upland border (Figure 3a, upper edge of the marsh in the 230 plot), but that pattern was not evident during the other maximum or the minima.

231 The calibration coefficients for the least-squares regressions of porewater salinity versus 232 conductivity for the 24 sample events ranged from $0.13-0.92$ at the NAR site and $0.01-0.75$ at 233 PAS (Table 1). The coefficients, as well as error prediction parameters, were highly variable 234 between events, without any consistent patterns or trends in the values at either site. Calculated 235 salinities for each sampling event at NAR ranged from 16.3 - $35.4 \mathrm{ppt}$, with an overall mean for 236 the entire study of $25.8 \pm 5.5 \mathrm{ppt}$ (Table 2). Calculated salinities at PAS ranged from $8.3-26.2$ 237 ppt, with an overall mean for the entire study of $17.7 \pm 5.3 \mathrm{ppt}$ (Table 2 ). While the overall mean 238 calculated salinity showed a difference of $8.1 \mathrm{ppt}$ between the two sites, for a given sample event 239 the differences varied from $0.8-15.8 \mathrm{ppt}$. Mean calculated salinities for both sites showed 240 maxima during the September 16, 2016 and October 27, 2017 sampling events (Figure 4). Mean 241 calculated salinities showed minima during the May 4, 2016 and June 15, 2017 sampling events 242 for NAR, and the May 4, 2016 and July 21, 2017 sampling events for PAS (Figure 4).

243 Linear regression models of whole-marsh calculated salinity versus environmental factors best

244 supported by the data included one-month and 6-month cumulative rainfall and tide state for both 245 sites (Table 3). At NAR, 6-month cumulative rainfall had the highest relative importance, about 2461.7 times that of tide state and 3 times that of one-month cumulative rainfall (Table 4). At PAS, 247 the factors 6-month and one-month cumulative rainfall had essentially equivalent relative 248 importance, slightly greater than that of tidal height (Table 4). 
249 Soil bulk density ranged from $0.16-0.34 \mathrm{~g} \mathrm{~cm}^{-3}$ across the two sites (Table 5) and differed 250 among marsh zones at PAS (ANOVA: $\mathrm{df}=2, \mathrm{~F}=7.952, \mathrm{p}=0.006$; Tukey - Kramer test: low 251 marsh differs significantly from mid and high marsh). Soil percent moisture ranged from $69.0-$

$25284.3 \%$ (Table 5), and, when averaged across the entire marsh, was greater at PAS $(81.5 \pm 3.6 \%)$ 253 than at NAR $(74.9 \pm 11.5 \%$; t-test: $\mathrm{df}=28 ; \mathrm{t}=2.105 ; \mathrm{p}=0.044)$. Percent moisture also differed 254 among zones at PAS (ANOVA: $\mathrm{df}=2, \mathrm{~F}=27.276, \mathrm{p}<0.001$; Tukey - Kramer test: low marsh 255 differs significantly from mid and high marsh).

256 Calculated salinity was significantly negatively correlated with elevation at NAR during the 12

257 sample events on or around the salinity maxima and minima (Table 6). Slopes of the regression 258 equations did not differ significantly between the maximum and minimum events. Elevation at 259 NAR across all sample points during the 12 sample events ranged from $1.06-1.90 \mathrm{ft}$, with a 260 mean of $1.54 \mathrm{ft}$. At the PAS site, calculated salinity was significantly negatively correlated with 261 elevation for only the June and August 2017 maxima, and the October 2016 and September 2017 262 minima (Table 6). At PAS slopes of the regression equations also did not differ significantly 263 between the maximum and minimum events. Elevation at PAS across all sample points during 264 the 12 sample events ranged from $0.62-1.02 \mathrm{~m}$, with a mean of $0.87 \mathrm{~m}$.

\section{Discussion}

266 Contours of calculated salinity showed both inter- and intra-marsh differences at our sites, and 267 differences were variable over time throughout the study. At NAR, contours showed an 268 expected pattern of soil salinity with higher values near the creek edge and lower towards the 269 upland border. This pattern was generally maintained except during one period of high salinity 270 incorporating the September 16, 2016 sampling event, when overall marsh salinity was at its 271 highest. This sampling event followed a period of relatively severe drought in the region which 
272 occurred from early spring through the fall of 2016. During this drought, the impact of

273 evapotranspiration on marsh hydrology may have been more pronounced and could have resulted

274 in reduced groundwater recharge from uplands, and hence greater seawater influence. Several

275 studies have modeled salt marsh groundwater dynamics and water table position by considering

276 groundwater flow as a shallow, rigid aquifer in contact with a sinusoidally oscillating reservoir,

277 and predicted the potential for greater seawater inflow in the absence of groundwater inputs

278 (Montalto et al 2007, Li and Jiao 2003). In northeast US salt marshes, seawater influence has

279 been shown to diminish as distance from tidal creeks increases (Hemmond and Fifield 1982), but

280 during periods of extreme drought and lowered water table levels the effects of seawater

281 inundation may be seen even in more interior portions of the marsh. However, globally many

282 factors affect the characteristic salinity of tidal wetlands, and patterns that we observe locally

283 may not be apparent depending on wetland type and location (Mitsch and Gosselink 2000). For

284 example, extensive freshwater inflow contributes to the characteristic salinities observed in

285 Mississippi delta, USA wetlands, and marshes can also be influenced by seawater inflow can

286 also exhibit uniform patterns of high soil salinity. Other examples of unique salinity patterns in

287 tidal wetlands include observed wider ranges of salinity in Australian mangroves (Boto and

288 wellington 1984), and higher overall salinities in Hudson Bay, Canada wetlands that are

289 attributed to fossil salt deposits (Price and Woo 1988).

290 At PAS, intra-marsh differences were not as distinct, and the marsh often showed homogeneous

291 salinity patterns exemplified by the September 16, 2016 and July 21, 2017 sample events. This

292 may have been a result of the marsh having a relatively small surface area, or of enhanced

293 surface freshwater and groundwater inputs. Elevation increases rapidly in the upland area

294 immediately bordering the marsh, and there is a small stream bordering the western portion. If 
295 the steep elevation serves to focus groundwater to the marsh, that along with the presence of the

296 stream may result in lower salinity levels during times of the year when there is little

297 evapotranspiration, and the effect may predominate over that of tidal inundation.

298 The NAR site is in the southern portion near the mouth of the Narragansett Bay estuary, and this 299 probably accounts for its measured mean whole-marsh calculated salinity being consistently 300 higher than that at PAS, which is located approximately $35 \mathrm{~km}$ to the north near the head of the 301 estuary. Mean surface seawater salinity at a long-term water quality sample site in Narragansett 302 Bay, located approximately $1 \mathrm{~km}$ north of PAS, averaged $25.1 \pm 0.8 \mathrm{ppt}$, while a site 303 approximately $4 \mathrm{~km}$ north of NAR averaged $31.5 \pm 0.2 \mathrm{ppt}(\mathrm{RM}$, unpublished data). These 304 values should approximate the salinity of the seawater inundating each marsh during flood tides. 305 Salinity of freshwater sources would likely vary somewhat both spatially and temporally, but 306 most likely had salinities less than 5 ppt (Dodds 2002). Nothing is known of the relative 307 contribution of each salinity end-member to porewater salinity at each site, still it is likely that 308 the lower seawater salinity near PAS contributed to the lower mean calculated salinities we 309 observed.

310 Mean calculated salinities for the marshes showed maxima roughly corresponding to late 311 summer, when plant biomass is high and evapotranspiration is assumed to be at its peak, and 312 minima in early to mid-spring when evapotranspiration is low and snow melt and rainfall could 313 lead to increased freshwater input to the marshes. Several studies have suggested a conceptual 314 model of factors influencing near-surface tidal marsh porewater salinity, lower salinity 315 freshwater inputs arising from groundwater flow under the marsh and surface water inputs 316 interacting with periodic inputs of higher salinity seawater delivered during semi-diurnal flood 317 tides (Barry et al. 1996, Li and Jiao 2003, Parlange et al. 1984). Variation in the position of the 
318 water table both spatially and temporally will determine soil saturation patterns and will

319 influence observed soil salinities across the marsh surface (Montalto et al. 2007). Results of

320 multiple linear regression models of cumulative regional rainfall, a driver of groundwater and

321 surface water inputs, and tide state versus our observed mean salinities in the marsh lend some

322 support to this model at our sites, with longer-term cumulative rainfall showing a greater relative

323 importance in our models than shorter-term precipitation, particularly at the PAS site. Longer-

324 term cumulative rainfall patterns may be more indicative of the magnitude of groundwater flow

325 to coastal marshes if groundwater flow in the watershed is relatively slow, say on the order of

$3260.002 \mathrm{~m} \mathrm{day}^{-1}$ as predicted in soils with hydraulic conductivity of $0.01 \mathrm{~m} \mathrm{day}^{-1}$ (Heath 1983).

327 However, many other factors not measured or accounted for in our study, including the timing

328 and magnitude of evapotranspiration, groundwater flow patterns under a marsh, marsh

329 topography, mean temperature, and variability in tidal inundation patterns will interact to

330 influence soil saturation and observed patterns of soil salinity across a marsh.

331 In soils with similar clay and organic matter content, $\mathrm{EC}_{\mathrm{a}}$ values will respond to changes in soil

332 composition, bulk density, moisture content, and soil salinity (Corwin and Lesch 2005).

333 Previous studies have suggested $\mathrm{EC}_{\mathrm{a}}$ could be a reliable means to rapidly assess soil salinity,

334 particularly in hydric soils (Sheets 1994, Hanson and Kaita 1997). In homogenous, uniformly

335 saturated salt marsh soils it may be reasonable to assume that $\mathrm{EC}_{\mathrm{a}}$ may accurately reflect changes

336 in soil salinity. However, regression statistics of the equations used to generate our calculated

337 salinity values, for example the variable correlation coefficient and slope values observed, could

338 be an indication that other soil parameters may be influencing $\mathrm{EC}_{\mathrm{a}}$ values at our sites. Soils at

339 our sites were consistently at or around $70 \%$ moisture, suggesting uniformly saturated soils that

340 would satisfy this assumption of the technique. We did see some intra-marsh differences in soil 
341 bulk density at PAS that may have contributed somewhat to variability in $\mathrm{EC}_{\mathrm{a}}$ values. It may also

342 be possible that our samples may have reflected spatial variation in soil composition at the sites:

343 if different regions of the marsh differed in soil composition, combining calibration data across

344 these regions may increase observed variability. Another possible explanation could be non-

345 homogeneous presence of conductive clay minerals or iron sulfate in the soils, both of which

346 may directly impact $\mathrm{EC}_{\mathrm{a}}$ values (Laforet 2011).

347 Variability in regression statistics can also be the result of spatial variability in porewater salinity

348 values, from vagaries in water table levels or groundwater flow at out sites. For example, in our

349 study $\mathrm{EC}_{\mathrm{a}}$ values reflected soil characteristics to $0.5 \mathrm{~m}$ below the marsh surface, while porewater

350 salinities used in the calibration equations were measured at a depth of $25 \mathrm{~cm}$. Spatial variability

351 in soil porewater salinity either above or below our porewater sample depth would be reflected in

$352 \quad \mathrm{EC}_{\mathrm{a}}$ values, but not necessarily in our measured pore water salinity values. Mean plant root

353 biomass at our sites is assumed to be around $0.4 \mathrm{~m}$ below the surface and may impact deeper

354 porewater dynamics that could would affect $\mathrm{EC}_{\mathrm{a}}$ values but not be reflected in our porewater

355 salinities. During seasonal extremes in salinity this could significantly influence interpretation or

356 misinterpret actual conditions in the rhizosphere that affect salinity-driven plant zonation

357 patterns. Addition of a second, deeper porewater salinity sampling point may help to resolve this

358 potential confounding factor. Differences in soil saturation may also have influenced our

359 measured $\mathrm{EC}_{\mathrm{a}}$ values, although to what extent is not clear. In a model of water table dynamics

360 and groundwater movement in a tidal marsh, Ursino et al. (2004) found that a zone of

361 unsaturated, aerated soil could form in a marsh in areas away from the hydraulic influence of

362 tidal creeks, and that this aerated zone could migrate toward the inner part of the marsh over

363 time. They also found that evapotranspiration can result in the formation of an unsaturated 
364 aerated layer trapped underneath saturated surface soil, particularly in areas away from the

365 influence of tidal creek hydrology (Ursino et al. 2004). Either of these phenomena could impact

$366 \mathrm{EC}_{\mathrm{a}}$ values while conceivably not impacting measured porewater salinity, and hence may

367 contribute to the variability in calibration statistics.

368 Correlations of calculated salinity with marsh elevation supported our qualitative assessment of

369 intra-marsh salinity variation shown by the contour plots. Calculated salinity at NAR

370 significantly correlated with elevation over all the examined sample events, reinforcing observed

371 patterns of higher soil salinity near the creek edge and lower salinity towards the upland border.

372 Previous studies have documented increases with soil elevation, reaching a maximum just above

373 mean high sea level and decreasing towards the upland edge of this marsh (Mahal and Park

374 1976, Adam 1990). These observations could be attributed to progressively less frequent

375 flooding of the marsh and the associated reduced salt input at higher elevations near the marsh

376 upland border (Adam 1990). At very high soil elevations, above MHSL, soil water salinity tends

377 to decrease due to. At PAS, the lack of significant correlation may have resulted from the more

378 homogenous salinity patterns observed across the marsh surface, or may have reflected the

379 predominance of groundwater or surface freshwater inputs at the site.

\section{Conclusions}

381 Results of our study suggest that despite variability in calibration coefficients, $\mathrm{EC}_{\mathrm{a}}$ values reflect

382 longer-term changes in porewater salinity at a single marsh. Therefore, $\mathrm{EC}_{\mathrm{a}}$ values show

383 promise in tracking spatial patterns of soil salinity over time at a given site, which could aid in

384 identifying changes in marsh biogeochemistry that could ultimately impact plant zonation. This

385 is particularly true under the assumption that ECa values are a dependable proxy for direct pore

386 water sampling once calibrated with actual field data: the relative ease of this technique makes 
387 mapping large or repeated spatial areas with EMI far more efficient than traditional approaches.

388 For example, $\mathrm{EC}_{\mathrm{a}}$ surveys of a marsh may aid in identifying areas of irregular seawater or

389 freshwater infiltration and help increase our understanding of marsh hydrology at a given site.

390 Several studies are underway in northeast US salt marshes to document shifts in high and low

391 marsh plant communities, in the context of increased flooding from sea level rise. Fine scale

392 mapping of salinity using EMI may aid in determining salinity patterns that will drive these

393 shifts before the plant species migrate. In this way, ECa mapping may aid in restoration planning

394 and monitoring, especially of low-lying coastal salt marshes vulnerable to sea level rise.

395 However, our results also suggest that inter-marsh comparisons of $\mathrm{EC}_{\mathrm{a}}$ values and calculated

396 salinities should be interpreted with caution: to accurately compare values, soil composition will

397 either need to be similar, or between marsh differences adequately characterized and considered

398 during the calibration process.

399 Acknowledgements

400 We thank Nicole Gutierrez and Katelyn Szura for assistance with initial sample protocol

401 development, and Jara Botelho, Jess Janiec, and Tia Mitchell for assistance with data collection.

402 Cathy Wigand, Sandi Robinson, Steve Shivers and Suzy Ayvazian provided helpful input on an

403 earlier version of this manuscript. The views expressed in this paper are those of the authors and

404 do not necessarily reflect the views or policies of the US Environmental Protection Agency. This

405 contribution is identified by Tracking Number ORD-028876 of the Atlantic Ecology Division,

406 Office of Research and Development, National Health and Environmental Effects Research

407 Laboratory. Mention of trade names, products, or services does not convey, and should not be

408 interpreted as conveying, official EPA approval, endorsement, or recommendation. 


\section{References}

412

413 Adam P. 1990. Saltmarsh Ecology. Cambridge University Press, Cambridge, UK, 461 pp.

414

415 Al Hassan M, Estrelles E, Soriano P, Lopez-Gresa MP, Belles JM, Boscaiu M, Vicente O. 2017.

416 Unraveling salt tolerance mechanisms in halophytes: a comparative study on four Mediterranean

417 Limonium species with different geographic distribution patterns. Frontiers in Plant Science 8, 418 Article No. 1438.

419

420

Barry DA, Barry SJ, Parlange JY. 1996. Capillarity correction to periodic solutions of the 421 shallow flow approximation, in Mixing in Estuaries and Coastal Seas, Coastal Estuarine Studies, 422 vol. 5, edited by C. Pattiaratchi, pp. 496-510, AGU, Washington, D. C.

423

424

Bricker-Urso S, Nixon SW, Cochran JK, Hirschberg DJ, Hunt C. 1989. Accretion rates and 425 sediment accumulation in Rhode Island salt marshes. Estuaries 12:300-317.

426

427 Burnham KP, Anderson DR. 2002. Model selection and multimodel inference: a practical 428 information-theoretic approach, 2nd edition. Springer-Verlag, New York, p. 488.

429

430 Corwin DL, Lesch SM. 2004. Apparent soil electrical conductivity measurements in agriculture. 431 Computers and Electronics in Agriculture 46:11-43. 432 
433 DeJong E, Ballantyne AK, Cameron DR, Read DWL. 1979. Measurement of apparent electrical 434 conductivity of soils by an electromagnetic induction probe to aid salinity surveys. Soil Science 435 Society of America Journal 43:810-812.

436

437 Dodds WK. 2002. Freshwater Ecology: Concepts and environmental applications. Academic 438 Press, New York, 567 pp.

439

440 Doolittle J, Petersen M, Wheeler T. 2001. Comparison of two electromagnetic induction tools in 441 salinity appraisals. Journal of Soil and Water Conservation 56:257-262.

442

443 Geonics Limited. 2014. EM38 ground conductivity meter operating manual. Mississauga, 444 Ontario, Canada.

445

446 Hanson BR, Kaita K. 1997. Response of electromagnetic conductivity meter to soil salinity and 447 soil-water content. Journal of Irrigation and Drainage Engineering 123:141-143.

448

449 Heath RC. 1983. Basic ground-water hydrology. U.S. Geological Survey Water-Supply Paper $4502220,86 \mathrm{pp}$.

451

452 Hemmond HF, Fifield JL. 1982. Subsurface flow in salt marsh peat: A model and field study.

453 Limnology and Oceanography 27:126-136.

454 
455 Kelleway JJ, Cavanaugh K, Rogers, K, Feller, Ilka C, Ens E, Doughty C, Saintilan N. 2017.

456 Review of the ecosystem service implications of mangrove encroachment into salt marshes.

457 Global Change Biology 23:3967-3983.

458

459 Laforet Z. 2011. Indirect measuring of soil conductivity for the calculation of pore water salinity 460 in tidal marshes. New Hampshire Sea Grant Tech 797, University of New Hampshire, Durham, $461 \mathrm{NH}$.

462

463 Li H, Jiao JJ. 2003. Influence of the tide on the mean watertable in an unconfined, anisotropic, 464 inhomogeneous coastal aquifer. Advances in Water Resources 26:9-16.

465

466 Mahal BE, Park RB. 1976. The ecotone between Spartina foliosa Trin Salicornia virginica L. in 467 salt marshes of northern San Francisco Bay. II. Soil water and salinity. Journal of Ecology, $468 \quad 64: 793-809$.

469

470 Montalto FA, Parlange JY, Steenhuis TS. 2007. A simple model for predicting water table

471 fluctuations in a tidal marsh. Water Resources Research 43:W03439,

472 doi:10.1029/2004WR003439.

473

474 Moore GE, Burdick DM, Peter CR, Keirstead DR. 2011. Mapping soil pore water salinity of 475 tidal marsh habitats using electromagnetic induction in Great Bay Estuary, USA. Wetlands $476 \quad 31: 309-318$.

477 
478 Paine JG, White WA, Smyth RC, Andrews JR, Gibeaut JC. 2004. Mapping coastal environments 479 with lidar and EM on Mustang Island, Texas, U.S. The Leading Edge Summer: 894-898.

480

481 Parlange JY, Stagnitti F,Starr JL,Braddock RD. 1984. Freesurface flow in porous media and 482 periodic solution of the shallow flow approximation. Journal of Hydrology 70:251-263.

483

484 Portnoy JW, Valiela I. 1997. Short-term effects of salinity reduction and drainage on salt-marsh 485 biogeochemical cycling and Spartina (cordgrass) production. Estuaries 20:569-578.

486

487 Robinson DA, Lebron I, Lesch SM, Shouse P. 2004. Minimizing drift in electrical conductivity 488 measurements in high temperature environments using the EM-38. Soil Science Society of 489 America Journal 68:339-345.

490

491 Sheets KR, Taylor JP, Hendrickx JMH. 1994. Rapid salinity mapping by electromagnetic 492 induction for determining riparian restoration potential. Restoration Ecology 2:242-246. 493

494 Silvestri S., Marani M. 2004. Salt-marsh vegetation and morphology: basic physiology, 495 modelling and remote sensing observations. Pages 1-21 in 'Ecogeomorphology of Tidal 496 Marshes',: S. Fagherazzi, L. Blum, Marani M, Eds., American Geophysical Union, Coastal and 497 Estuarine Monograph Series, 2004. 
499 Smith SM, Tyrrell M, Medeiros K, Bayley H, Fox S, Adams M, Mejia C, Dijkstra A, Janson S, 500 Tanis M. 2017. Hypsometry of Cape Cod salt marshes (Massachusetts, U.S.A.) and predictions 501 of marsh vegetation responses to sea-level rise. Journal of Coastal Research 33:537-547.

502

503 Turner RE, Swenson EM, Milan CS. 2000. Organic and inorganic contributions to vertical 504 accretion in salt marsh sediments. In: Weinstein MP, Kreeger DA (eds.), Concepts and 505 Controversies in Tidal Marsh Ecology. Dordrecht, The Netherlands: Springer, pp. 583-595. 506

507 Ursino N, Silvestri S, Marani M. 2004 Subsurface flow and vegetation patterns in tidal 508 environments. Water Resources Research 40:W05115, doi:10.1029/2003WR002702.

509

510 Watson EB, Wigand C, Davey EW, Andrews HM, Bishop J, Raposa KB. 2017. Wetland loss 511 patterns and inundation-productivity relationships prognosticate widespread salt marsh loss for 512 southern New England. Estuaries and Coasts 40:662-681.

513 


\section{Table $\mathbf{1}$ (on next page)}

Coefficients of calibration (root mean square error dependent means), sum of squared residuals, predicted residual sum of squares, and calibration coefficients from least squares regressions of apparent conductivity $\left(\mathrm{EC}_{\mathrm{a}}\right)$ values and measured por 
1 a.)

\begin{tabular}{|c|c|c|c|c|}
\hline $\begin{array}{c}\text { NAR Sample } \\
\text { Date }\end{array}$ & $\begin{array}{c}\text { Coefficient of } \\
\text { Variation }\end{array}$ & $\begin{array}{c}\text { Sum of } \\
\text { Squared } \\
\text { Residuals }\end{array}$ & $\begin{array}{c}\text { Predicted } \\
\text { Residual Sum } \\
\text { of Squares }\end{array}$ & $\begin{array}{c}\text { Calibration } \\
\text { Coefficient (r' }\end{array}$ \\
\hline 30 Oct 2015 & 29.842 & 79191 & 110199 & 0.78 \\
\hline 4 Dec 2015 & 39.236 & 97394 & 122353 & 0.56 \\
\hline 30 Dec 2015 & 52.270 & 180068 & 223680 & 0.46 \\
\hline 29 Jan 2016 & 49.536 & 180847 & 249408 & 0.16 \\
\hline 7 Mar 2016 & 27.860 & 40988 & 64366 & 0.66 \\
\hline 6 Apr 2016 & 63.626 & 156358 & 235861 & 0.13 \\
\hline 4 May 2016 & 30.083 & 94784 & 124701 & 0.25 \\
\hline 1 June 2016 & 18.678 & 15643 & 22136 & 0.92 \\
\hline 24 June 2016 & 29.803 & 121322 & 164145 & 0.63 \\
\hline 4 Aug 2016 & 29.259 & 182849 & 242562 & 0.44 \\
\hline 16 Sept 2016 & 28.051 & 199277 & 271598 & 0.27 \\
\hline 7 Oct 2016 & 22.674 & 128346 & 164483 & 0.61 \\
\hline 28 Oct 2016 & 31.011 & 245924 & 303635 & 0.42 \\
\hline 1 Dec 2016 & 28.961 & 530237 & 612677 & 0.41 \\
\hline 30 Dec 2016 & 49.937 & 311022 & 367100 & 0.37 \\
\hline 29 Jan 2017 & 34.739 & 192455 & 241947 & 0.41 \\
\hline 2 Mar 2017 & 40.657 & 182386 & 205666 & 0.66 \\
\hline 29 Mar 2017 & 51.991 & 285369 & 354594 & 0.37 \\
\hline 3 May 2017 & 34.691 & 73862 & 218634 & 0.36 \\
\hline 15 June 2017 & 43.591 & 265452 & 320012 & 0.44 \\
\hline 21 July 2017 & 17.821 & 63612 & 101593 & 0.77 \\
\hline 16 Aug 2017 & 32.059 & 293982 & 349819 & 0.51 \\
\hline 14 Sept 2017 & 26.958 & 175088 & 208907 & 0.67 \\
\hline 27 Oct 2017 & 28.873 & 153907 & 185583 & 0.54 \\
\hline
\end{tabular}

2 
$4 \quad$ b.)

\begin{tabular}{|c|c|c|c|c|}
\hline $\begin{array}{c}\text { PAS Sample } \\
\text { Date }\end{array}$ & $\begin{array}{c}\text { Coefficient of } \\
\text { Variation }\end{array}$ & $\begin{array}{c}\text { Sum of } \\
\text { Squared } \\
\text { Residuals }\end{array}$ & $\begin{array}{c}\text { Predicted } \\
\text { Residual Sum } \\
\text { of Squares }\end{array}$ & $\begin{array}{c}\text { Calibration } \\
\text { Coefficient (r') }\end{array}$ \\
\hline 30 Oct 2015 & 19.582 & 17318 & 26474 & 0.72 \\
\hline 4 Dec 2015 & 15.152 & 5285 & 14160 & 0.12 \\
\hline 30 Dec 2015 & 19.609 & 8638 & 17363 & 0.58 \\
\hline 29 Jan 2016 & 22.107 & 11722 & 18318 & 0.31 \\
\hline 7 Mar 2016 & 16.840 & 3413 & 6002 & 0.53 \\
\hline 6 Apr 2016 & 14.834 & 2537 & 10192 & 0.34 \\
\hline 4 May 2016 & 21.255 & 8471 & 15126 & 0.33 \\
\hline 1 June 2016 & 21.049 & 8861 & 20611 & 0.13 \\
\hline 24 June 2016 & 19.900 & 15849 & 49975 & 0.01 \\
\hline 4 Aug 2016 & 8.183 & 4505 & 7272 & 0.65 \\
\hline 16 Sept 2016 & 14.158 & 18307 & 29701 & 0.19 \\
\hline 7 Oct 2016 & 12.061 & 12432 & 16553 & 0.42 \\
\hline 28 Oct 2016 & 13.408 & 14472 & 21083 & 0.29 \\
\hline 1 Dec 2016 & 15.753 & 12759 & 17545 & 0.28 \\
\hline 30 Dec 2016 & 13.911 & 6212 & 8928 & 0.59 \\
\hline 29 Jan 2017 & 20.937 & 14154 & 20493 & 0.20 \\
\hline 2 Mar 2017 & 22.898 & 20047 & 31109 & 0.29 \\
\hline 29 Mar 2017 & 18.886 & 12726 & 15743 & 0.52 \\
\hline 3 May 2017 & 20.705 & 9135 & 13823 & 0.59 \\
\hline 15 June 2017 & 16.959 & 11120 & 18111 & 0.75 \\
\hline 21 July 2017 & 18.769 & 10313 & 21309 & 0.13 \\
\hline 16 Aug 2017 & 15.431 & 14303 & 19796 & 0.16 \\
\hline 14 Sept 2017 & 14.038 & 14023 & 22991 & 0.52 \\
\hline 27 Oct 2017 & 13.628 & 10648 & 18538 & 0.59 \\
\hline
\end{tabular}




\section{Table 2 (on next page)}

Mean whole-marsh conductivity ( $\pm \mathrm{SE}$ ), measured pore water salinity, and calculated salinity, and coefficients from least squares regressions used for calibration for 24 sample events at the a) southern (NAR) and b) northern (PAS) study sites.

Conductivity and calculated salinity were averaged across all sample points on the marsh surface, and measured pore water salinity was averaged across the sub-set of sample points where pore water was collected. Calibration coefficients for the corresponding calibration curves were constructed from a least squares regression of apparent conductivity $\left(\mathrm{EC}_{\mathrm{a}}\right)$ values and measured pore water salinities. 
a.)

\begin{tabular}{|c|c|c|c|c|}
\hline $\begin{array}{c}\text { NAR Sample } \\
\text { Date }\end{array}$ & $\begin{array}{c}\text { Mean } \\
\text { Conductivity } \\
\left(\mathrm{mS} \mathrm{m}^{-1}\right)\end{array}$ & $\begin{array}{c}\text { Mean } \\
\text { Measured Pore } \\
\text { Water Salinity } \\
\text { (ppt) }\end{array}$ & $\begin{array}{c}\text { Mean } \\
\text { Calculated } \\
\text { Salinity (ppt) }\end{array}$ & $\begin{array}{c}\text { Calibration } \\
\text { Coefficient (r })^{2}\end{array}$ \\
\hline 30 Oct 2015 & $317.7 \pm 24.5$ & $24.3 \pm 4.0$ & $23.4 \pm 1.5$ & 0.78 \\
\hline 4 Dec 2015 & $238.4 \pm 18.8$ & $25.1 \pm 2.9$ & $26.2 \pm 1.3$ & 0.56 \\
\hline 30 Dec 2015 & $249.4 \pm 21.4$ & $23.7 \pm 3.1$ & $24.5 \pm 1.0$ & 0.46 \\
\hline 29 Jan 2016 & $222.7 \pm 20.5$ & $25.6 \pm 2.4$ & $24.7 \pm 0.8$ & 0.16 \\
\hline 7 Mar 2016 & $213.6 \pm 20.2$ & $22.8 \pm 3.8$ & $18.2 \pm 1.6$ & 0.66 \\
\hline 6 Apr 2016 & $191.6 \pm 17.8$ & $21.4 \pm 2.3$ & $21.5 \pm 0.8$ & 0.13 \\
\hline 4 May 2016 & $193.6 \pm 18.3$ & $20.0 \pm 2.5$ & $16.3 \pm 0.9$ & 0.25 \\
\hline 1 June 2016 & $261.5 \pm 24.3$ & $15.9 \pm 3.8$ & $17.7 \pm 1.6$ & 0.92 \\
\hline 24 June 2016 & $305.7 \pm 23.2$ & $22.7 \pm 2.3$ & $20.3 \pm 1.0$ & 0.63 \\
\hline 4 Aug 2016 & $402.6 \pm 21.9$ & $34.0 \pm 2.0$ & $33.9 \pm 1.3$ & 0.44 \\
\hline 16 Sept 2016 & $389.0 \pm 21.6$ & $36.1 \pm 1.3$ & $35.4 \pm 0.4$ & 0.27 \\
\hline 7 Oct 2016 & $388.1 \pm 18.0$ & $34.4 \pm 1.3$ & $34.6 \pm 1.1$ & 0.61 \\
\hline 28 Oct 2016 & $386.7 \pm 19.4$ & $35.3 \pm 1.4$ & $35.2 \pm 1.0$ & 0.42 \\
\hline 1 Dec 2016 & $491.5 \pm 33.9$ & $32.7 \pm 1.4$ & $31.2 \pm 1.1$ & 0.41 \\
\hline 30 Dec 2016 & $263.1 \pm 20.2$ & $29.6 \pm 2.3$ & $28.8 \pm 1.0$ & 0.37 \\
\hline 29 Jan 2017 & $269.6 \pm 16.9$ & $28.8 \pm 2.7$ & $27.1 \pm 1.2$ & 0.41 \\
\hline 2 Mar 2017 & $252.2 \pm 19.4$ & $21.3 \pm 2.4$ & $22.6 \pm 1.3$ & 0.66 \\
\hline 29 Mar 2017 & $253.0 \pm 22.5$ & $23.5 \pm 2.1$ & $23.1 \pm 1.0$ & 0.37 \\
\hline 3 May 2017 & $245.0 \pm 16.9$ & $24.7 \pm 1.9$ & $23.0 \pm 1.0$ & 0.36 \\
\hline 15 June 2017 & $295.7 \pm 20.7$ & $21.6 \pm 2.1$ & $21.3 \pm 0.9$ & 0.44 \\
\hline 21 July 2017 & $347.8 \pm 19.4$ & $26.6 \pm 2.1$ & $24.9 \pm 1.2$ & 0.77 \\
\hline 16 Aug 2017 & $353.9 \pm 18.4$ & $27.9 \pm 1.9$ & $26.7 \pm 0.9$ & 0.51 \\
\hline 14 Sept 2017 & $381.3 \pm 16.8$ & $27.0 \pm 2.1$ & $27.6 \pm 0.9$ & 0.67 \\
\hline 27 Oct 2017 & $339.4 \pm 18.6$ & $30.5 \pm 1.5$ & $30.2 \pm 1.0$ & 0.54 \\
\hline
\end{tabular}


$4 \quad$ b.)

\begin{tabular}{|c|c|c|c|c|}
\hline $\begin{array}{c}\text { PAS Sample } \\
\text { Date }\end{array}$ & $\begin{array}{c}\text { Mean } \\
\text { Conductivity } \\
\left(\mathrm{mS} \mathrm{m}^{-1}\right)\end{array}$ & $\begin{array}{c}\text { Mean } \\
\text { Measured Pore } \\
\text { Water Salinity } \\
\mathbf{( p p t )}\end{array}$ & $\begin{array}{c}\text { Mean } \\
\text { Calculated } \\
\text { Salinity (ppt) }\end{array}$ & $\begin{array}{c}\text { Calibration } \\
\text { Coefficient (r }\end{array}$ \\
\hline 30 Oct 2015 & $249.7 \pm 9.5$ & $20.5 \pm 2.0$ & $21.3 \pm 1.0$ & 0.72 \\
\hline 4 Dec 2015 & $207.7 \pm 7.5$ & $21.9 \pm 1.4$ & $22.4 \pm 0.9$ & 0.12 \\
\hline 30 Dec 2015 & $193.8 \pm 7.6$ & $16.6 \pm 2.8$ & $16.7 \pm 1.2$ & 0.58 \\
\hline 29 Jan 2016 & $176.7 \pm 7.8$ & $15.1 \pm 1.3$ & $14.7 \pm 1.1$ & 0.31 \\
\hline 7 Mar 2016 & $151.7 \pm 6.4$ & $11.9 \pm 1.3$ & $17.4 \pm 0.7$ & 0.53 \\
\hline 6 Apr 2016 & $146.9 \pm 6.7$ & $10.9 \pm 1.6$ & $11.4 \pm 1.0$ & 0.34 \\
\hline 4 May 2016 & $154.1 \pm 6.7$ & $8.7 \pm 1.3$ & $8.3 \pm 0.5$ & 0.33 \\
\hline 1 June 2016 & $183.2 \pm 7.3$ & $9.1 \pm 1.4$ & $8.6 \pm 0.5$ & 0.13 \\
\hline 24 June 2016 & $227.8 \pm 8.7$ & $14.4 \pm 1.7$ & $16.8 \pm 0.8$ & 0.01 \\
\hline 4 Aug 2016 & $272.4 \pm 9.7$ & $22.5 \pm 1.8$ & $23.7 \pm 1.6$ & 0.65 \\
\hline 16 Sept 2016 & $301.9 \pm 10.9$ & $26.7 \pm 1.0$ & $26.2 \pm 1.4$ & 0.19 \\
\hline 7 Oct 2016 & $296.7 \pm 8.6$ & $23.3 \pm 1.4$ & $23.7 \pm 1.3$ & 0.42 \\
\hline 28 Oct 2016 & $251.1 \pm 7.3$ & $25.6 \pm 0.8$ & $25.3 \pm 1.1$ & 0.29 \\
\hline 1 Dec 2016 & $233.7 \pm 5.9$ & $21.8 \pm 1.0$ & $22.0 \pm 1.1$ & 0.28 \\
\hline 30 Dec 2016 & $178.5 \pm 6.1$ & $22.3 \pm 1.3$ & $22.3 \pm 1.3$ & 0.59 \\
\hline 29 Jan 2017 & $172.5 \pm 5.6$ & $18.2 \pm 1.5$ & $18.9 \pm 0.9$ & 0.20 \\
\hline 2 Mar 2017 & $186.2 \pm 8.5$ & $13.7 \pm 1.2$ & $14.1 \pm 0.8$ & 0.29 \\
\hline 29 Mar 2017 & $168.9 \pm 6.2$ & $17.6 \pm 1.6$ & $17.3 \pm 0.9$ & 0.52 \\
\hline 3 May 2017 & $157.7 \pm 6.9$ & $14.7 \pm 2.2$ & $20.0 \pm 1.3$ & 0.59 \\
\hline 15 June 2017 & $199.1 \pm 8.4$ & $10.6 \pm 1.3$ & $12.3 \pm 0.7$ & 0.75 \\
\hline 21 July 2017 & $194.4 \pm 7.1$ & $9.0 \pm 0.5$ & $9.1 \pm 0.4$ & 0.13 \\
\hline 16 Aug 2017 & $240.4 \pm 6.6$ & $12.7 \pm 1.1$ & $13.2 \pm 0.6$ & 0.16 \\
\hline 14 Sept 2017 & $274.3 \pm 6.6$ & $18.4 \pm 1.0$ & $18.1 \pm 0.7$ & 0.52 \\
\hline 27 Oct 2017 & $263.0 \pm 6.1$ & $21.4 \pm 1.5$ & $21.1 \pm 1.0$ & 0.59 \\
\hline
\end{tabular}




\section{Table 3 (on next page)}

Best predictive models incorporating the effect of cumulative rainfall amounts and tide state at time of sampling on calculated salinity values during 24 sample events at the a) southern (NAR) and b) northern (PAS) study sites.

Models best supported by the data, or those having $\triangle \mathrm{AIC}_{\mathrm{c}}$ values between 0.00 and 2.00 , are listed. 
1 a.)

\begin{tabular}{|l|c|c|c|}
\hline NAR Model $^{\mathbf{a}}$ & $\mathbf{R}^{\mathbf{2}}$ & $\mathbf{A I C}_{\mathbf{c}}$ & $\boldsymbol{\Delta} \mathbf{A I C}_{\mathbf{c}}^{\mathbf{b}}$ \\
\hline $48.77-0.831(6 \mathrm{MON})-3.193(\mathrm{TIDE})$ & 0.55 & 69.12 & 0.00 \\
\hline $44.22-0.781(6 \mathrm{MON})$ & 0.48 & 70.13 & 1.01 \\
\hline $47.54-0.873(6 \mathrm{MON})-3.124(\mathrm{TIDE})+0.531(1 \mathrm{MON})$ & 0.57 & 70.78 & 1.66 \\
\hline
\end{tabular}

2

3 b.)

\begin{tabular}{|l|c|c|c|}
\hline PAS Model $^{\mathbf{a}}$ & $\mathbf{R}^{\mathbf{2}}$ & $\mathbf{A I C}_{\mathbf{c}}$ & $\boldsymbol{\Delta} \mathbf{A I C _ { \mathbf { c } }}$ \\
\hline $37.41-0.873(6 \mathrm{MON})-3.124(\mathrm{TIDE})+0.531(1 \mathrm{MON})$ & 0.80 & 50.55 & 0.00 \\
\hline
\end{tabular}

4

5 a $1 \mathrm{MON}=$ cumulative rainfall 30 days prior to sample event; $6 \mathrm{MON}=$ cumulative rainfall 180

6 days prior to sample event; TIDE $=$ tide state.

$7 \quad{ }^{\mathrm{b}} \Delta \mathrm{AIC}_{\mathrm{c}}=\mathrm{AIC}_{\mathrm{c} i}-\mathrm{AIC}_{\mathrm{cmin}}$

8 
Table 4 (on next page)

Relative importance of rainfall and tide parameters in regression models explaining calculated salinity values during 24 sample events at the southern (NAR) and northern (PAS) study sites. 
1

\begin{tabular}{|l|c|c|}
\hline Parameter & NAR Relative Importance & PAS Relative Importance \\
\hline $24 \mathrm{HR}$ & 0.195 & 0.188 \\
\hline $1 \mathrm{MON}$ & 0.327 & 0.999 \\
\hline $6 \mathrm{MON}$ & 1.000 & 1.000 \\
\hline TIDE & 0.596 & 0.966 \\
\hline
\end{tabular}

2 


\section{Table 5 (on next page)}

Mean bulk density and percent moisture in soil samples to $25 \mathrm{~cm}$ depth collected in high, mid, and low marsh locations at the a) southern (NAR) and b) northern (PAS) study sites. 
1

\begin{tabular}{|c|c|c|c|}
\hline Site & Location & $\begin{array}{c}\text { Bulk Density } \\
\left(\mathbf{g ~ c m}^{-3}\right)\end{array}$ & $\begin{array}{c}\text { Percent } \\
\text { Moisture (\%) }\end{array}$ \\
\hline NAR & High marsh & $0.31 \pm 0.04$ & $71.3 \pm 3.3$ \\
\hline NAR & Mid marsh & $0.19 \pm 0.01$ & $84.3 \pm 1.4$ \\
\hline NAR & Low marsh & $0.34 \pm 0.29$ & $69.0 \pm 16.8$ \\
\hline & & & \\
\hline PAS & High marsh & $0.24 \pm 0.05$ & $77.1 \pm 0.6$ \\
\hline PAS & Mid marsh & $0.17 \pm 0.02$ & $84.2 \pm 1.4$ \\
\hline PAS & Low marsh & $0.16 \pm 0.03$ & $83.2 \pm 2.4$ \\
\hline
\end{tabular}

2 


\section{Table 6(on next page)}

Least squares regression statistics for the relationship between calculated salinity and elevation for a sub-set of 12 sample events corresponding to calculated salinity maxima and minima over the course of the study at the a) southern (NAR) and b) northe 
1 a.)

\begin{tabular}{|l|c|c|c|c|}
\hline $\begin{array}{l}\text { NAR } \\
\text { Minima }\end{array}$ & Slope & $\mathbf{R}^{\mathbf{2}}$ & $\begin{array}{c}\text { Degrees of } \\
\text { Freedom }\end{array}$ & $\mathbf{p}$ \\
\hline Sample Date & -8.42 & 0.35 & 44 & $<0.001$ \\
\hline $4 / 6 / 2016$ & -25.47 & 0.54 & 52 & $<0.001$ \\
\hline $5 / 4 / 2016$ & -38.62 & 0.42 & 34 & $<0.001$ \\
\hline $6 / 1 / 2016$ & -21.72 & 0.55 & 58 & $<0.001$ \\
\hline $6 / 15 / 2017$ & -36.09 & 0.59 & 60 & $<0.001$ \\
\hline $7 / 21 / 2017$ & -24.99 & 0.63 & 61 & $<0.001$ \\
\hline $8 / 16 / 2017$ & & & & $\mathbf{p}$ \\
\hline $\begin{array}{l}\text { NAR } \\
\text { Maxima }\end{array}$ & Slope & $\mathbf{R}^{\mathbf{2}}$ & $\begin{array}{c}\text { Degrees of } \\
\text { Freedom }\end{array}$ \\
\hline Sample Date & -11.90 & 0.61 & 47 & $<0.001$ \\
\hline $9 / 16 / 2016$ & -15.56 & 0.57 & 52 & $<0.001$ \\
\hline $10 / 7 / 2016$ & -9.75 & 0.33 & 54 & $<0.001$ \\
\hline $10 / 28 / 2016$ & -27.62 & 0.53 & 76 & $<0.001$ \\
\hline $9 / 14 / 2017$ & -18.05 & 0.57 & 54 & $<0.001$ \\
\hline $10 / 27 / 2017$ & -24.68 & 0.55 & 61 & $<0.001$ \\
\hline $11 / 21 / 2017$ & & \multicolumn{2}{|c|}{} \\
\hline
\end{tabular}

2

3 b.)

\begin{tabular}{|c|c|c|c|c|}
\hline $\begin{array}{l}\text { PAS } \\
\text { Minima }\end{array}$ & & & & \\
\hline Sample Date & Slope & $\mathbf{R}^{2}$ & $\begin{array}{c}\text { Degrees of } \\
\text { Freedom }\end{array}$ & $\mathbf{p}$ \\
\hline $4 / 6 / 2016$ & 0.71 & 0.01 & 25 & 0.643 \\
\hline $5 / 4 / 2016$ & -0.34 & 0.01 & 30 & 0.556 \\
\hline $6 / 1 / 2016$ & -0.67 & 0.07 & 30 & 0.149 \\
\hline $6 / 15 / 2017$ & -4.10 & 0.37 & 36 & $<0.001$ \\
\hline $7 / 21 / 2017$ & 0.03 & 0.01 & 29 & 0.897 \\
\hline $8 / 16 / 2017$ & -1.11 & 0.20 & 33 & 0.007 \\
\hline $\begin{array}{l}\text { PAS } \\
\text { Maxima }\end{array}$ & & & & \\
\hline Sample Date & Slope & $\mathbf{R}^{2}$ & $\begin{array}{c}\text { Degrees of } \\
\text { Freedom }\end{array}$ & $\mathbf{p}$ \\
\hline $9 / 16 / 2016$ & -0.25 & 0.00 & 25 & 0.746 \\
\hline $10 / 7 / 2016$ & -4.54 & 0.34 & 30 & $<0.001$ \\
\hline $10 / 28 / 2016$ & 0.89 & 0.07 & 31 & 0.124 \\
\hline $9 / 14 / 2017$ & -1.51 & 0.12 & 39 & 0.024 \\
\hline $10 / 27 / 2017$ & -0.51 & 0.01 & 33 & 0.601 \\
\hline $11 / 21 / 2017$ & -0.11 & 0.00 & 35 & 0.907 \\
\hline
\end{tabular}


Figure 1

Location of the two salt marsh study sites Narrow River marsh (NAR) and Passeonkquis marsh (PAS) in the Narragansett Bay estuary, Rhode Island, USA. 


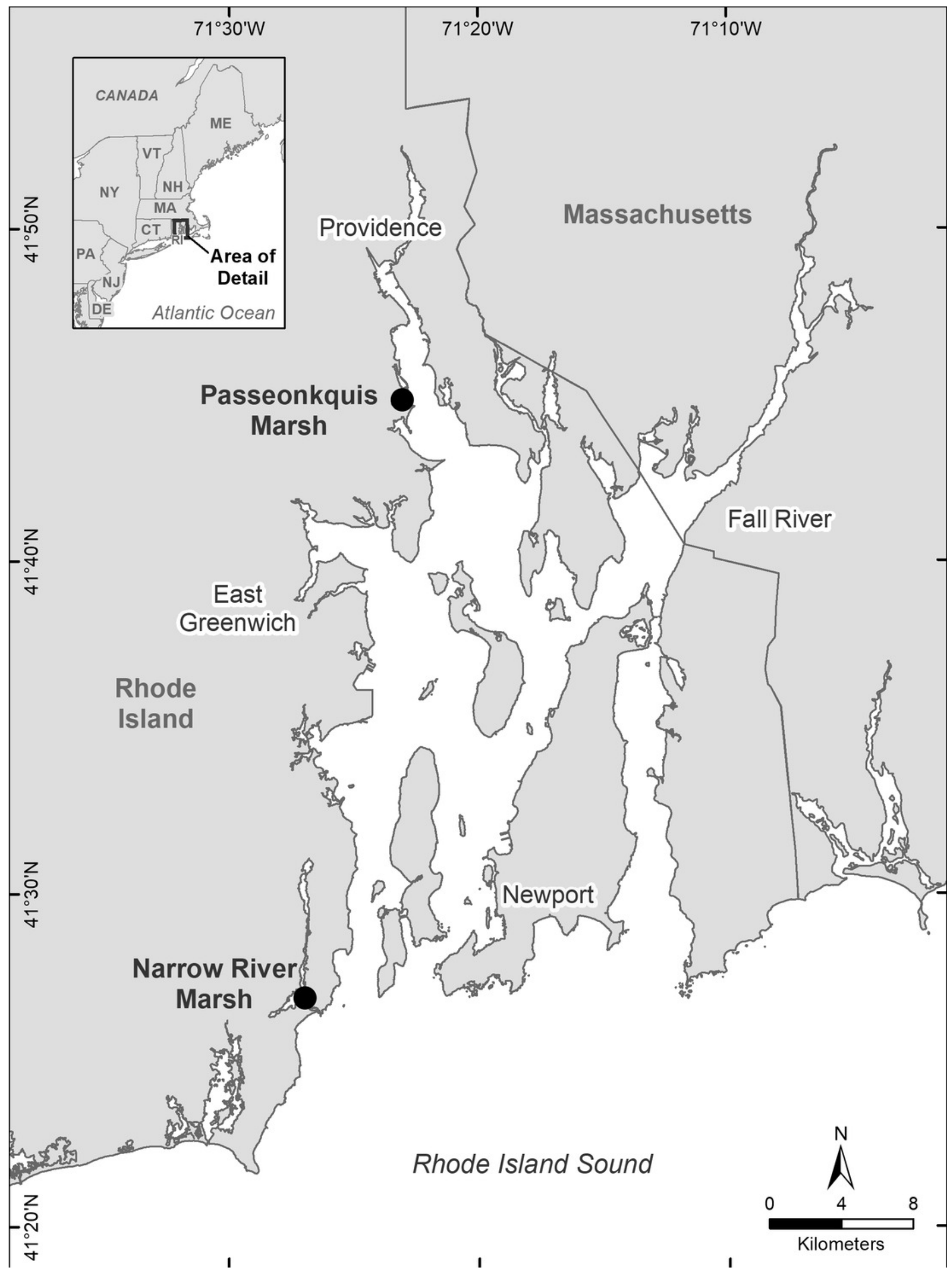


Figure 2

Contour plots of calculated salinity across the marsh surface of NAR generated using inverse distance weighted interpolation corresponding to the a.) and b.) mean calculated salinity maxima, and c.) and d.) mean calculated salinity minima.

a)

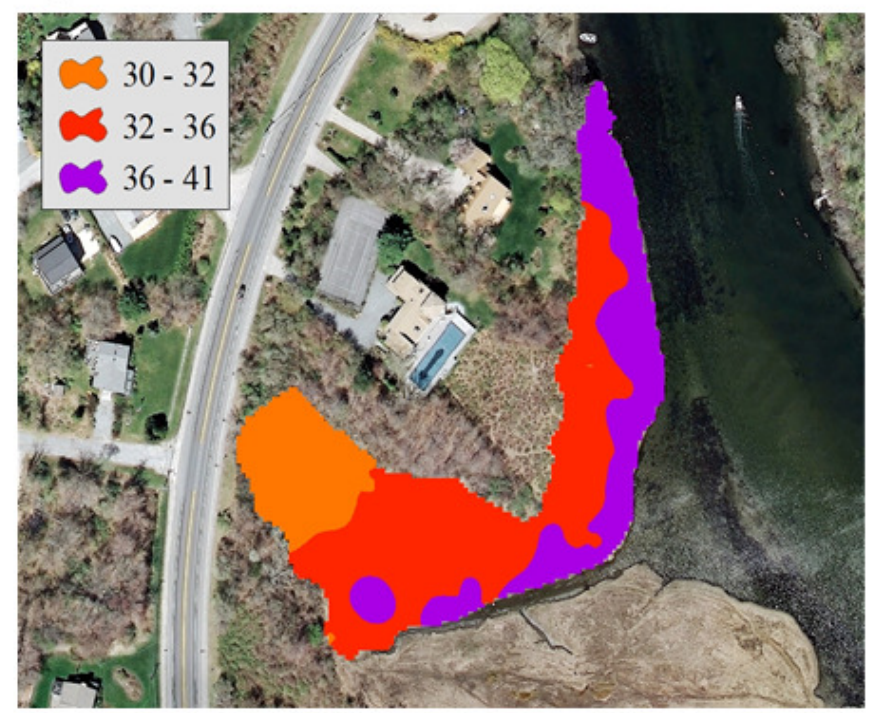

September 16, 2016

c)

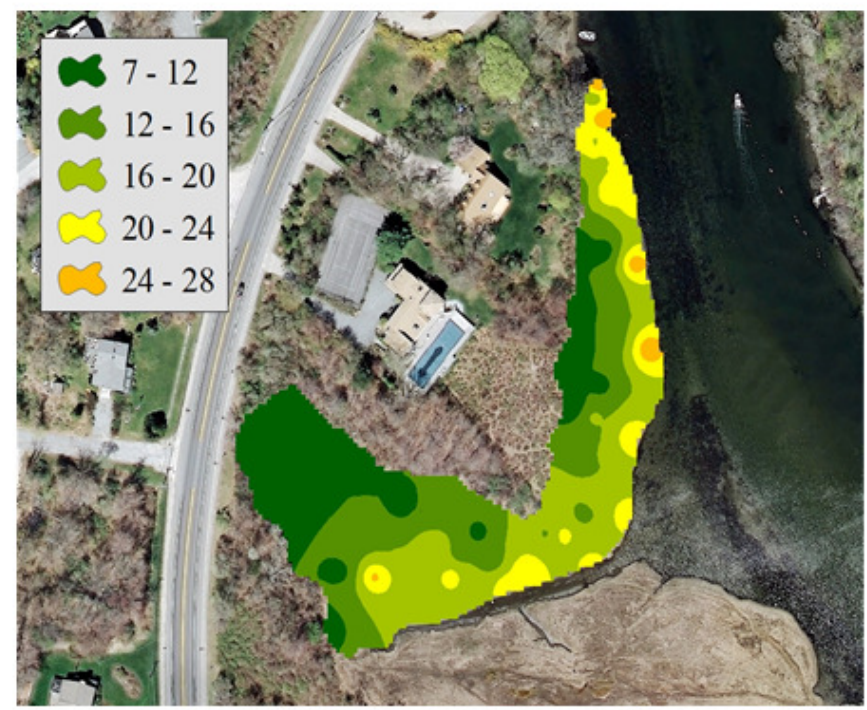

May 4, 2016 b)

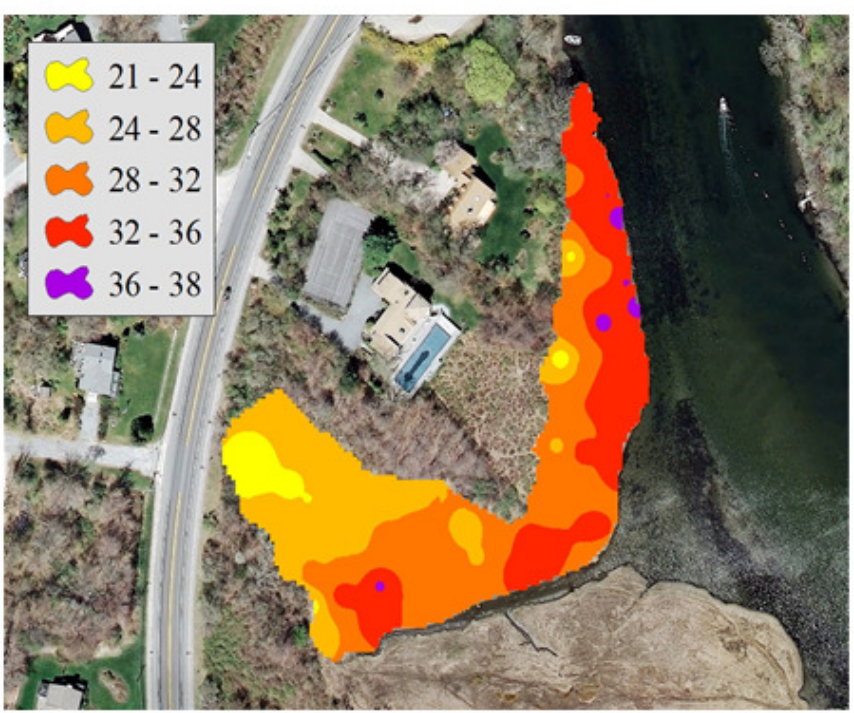

October 27, 2017

d)

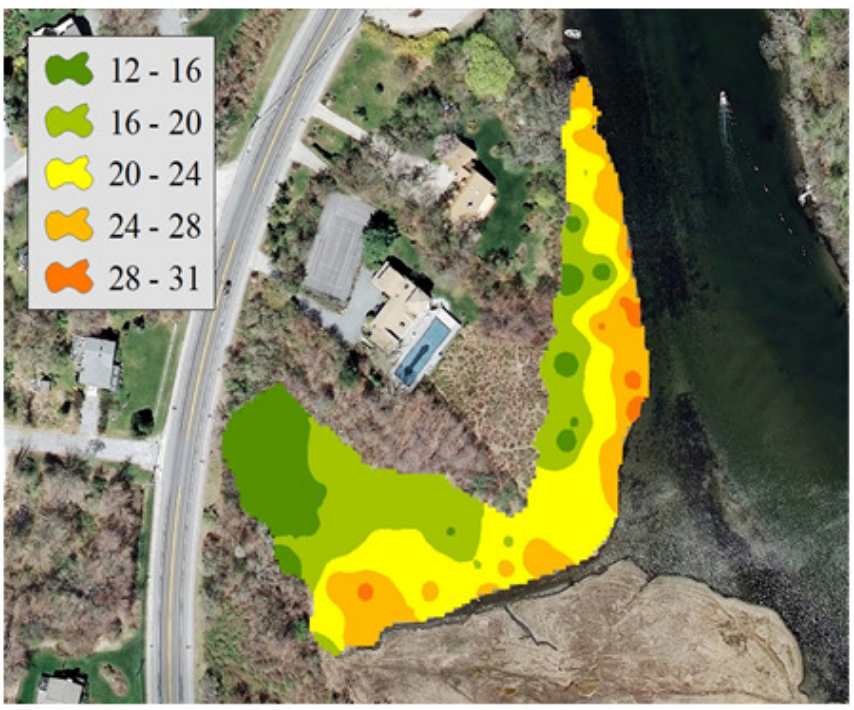

June 15, 2017 
Figure 3

Contour plots of calculated salinity across the marsh surface of PAS generated using inverse distance weighted interpolation corresponding to the a.) and b.) mean calculated salinity maxima, and c.) and d.) mean calculated salinity minima.

a)

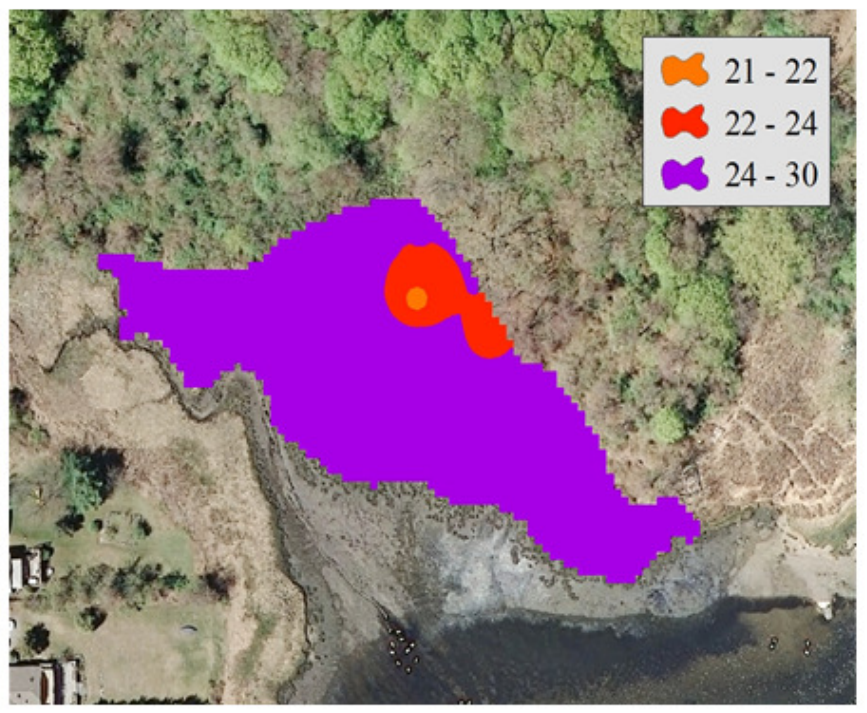

September 16, 2016

c)

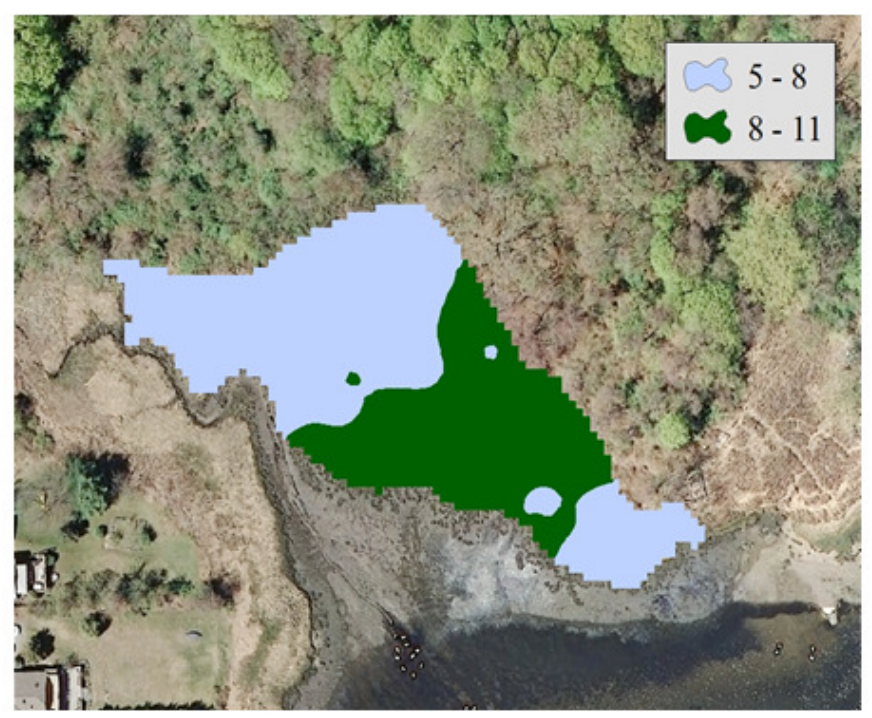

May 4, 2016 b)

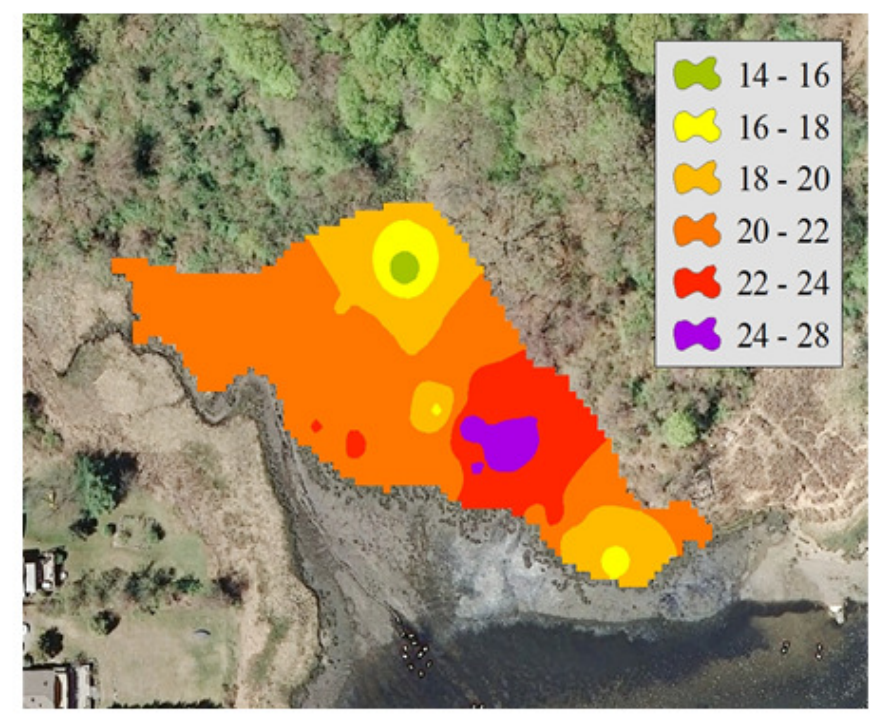

October 27, 2017

d)

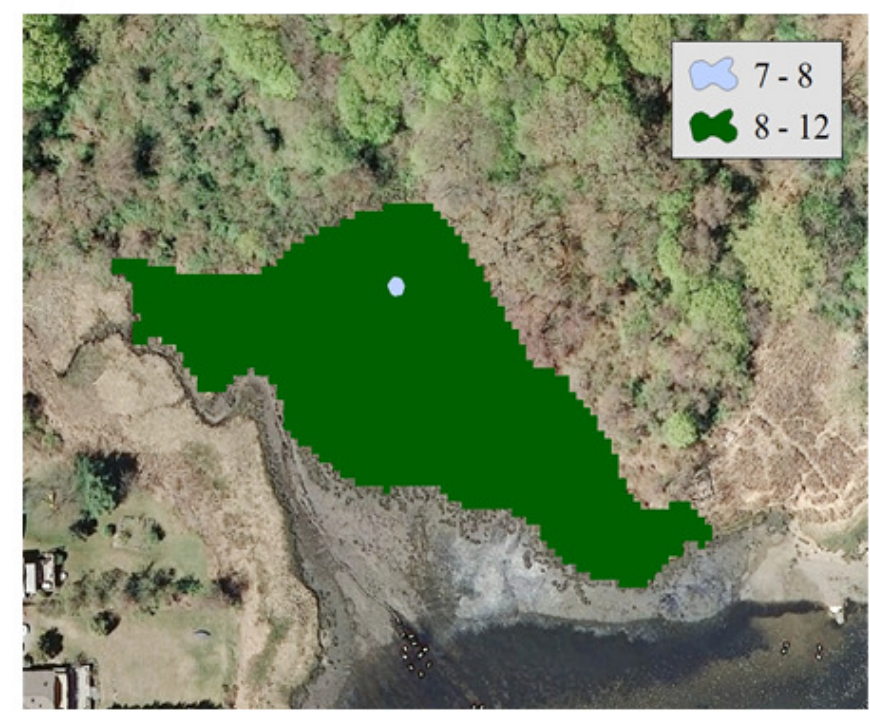

June 15, 2017 
Figure 4

Plot of mean whole-marsh calculated salinity versus day of sampling for the NAR and PAS study sites.

The date of the initial sample event October 30, 2015 was designated as day 1. Sample minima at days 188 and 631 corresponded to the dates May 4, 2016 and July 21, 2017. Sample maxima at days 323 and 729 corresponded to the dates September 16, 2016 and October 27, 2017.

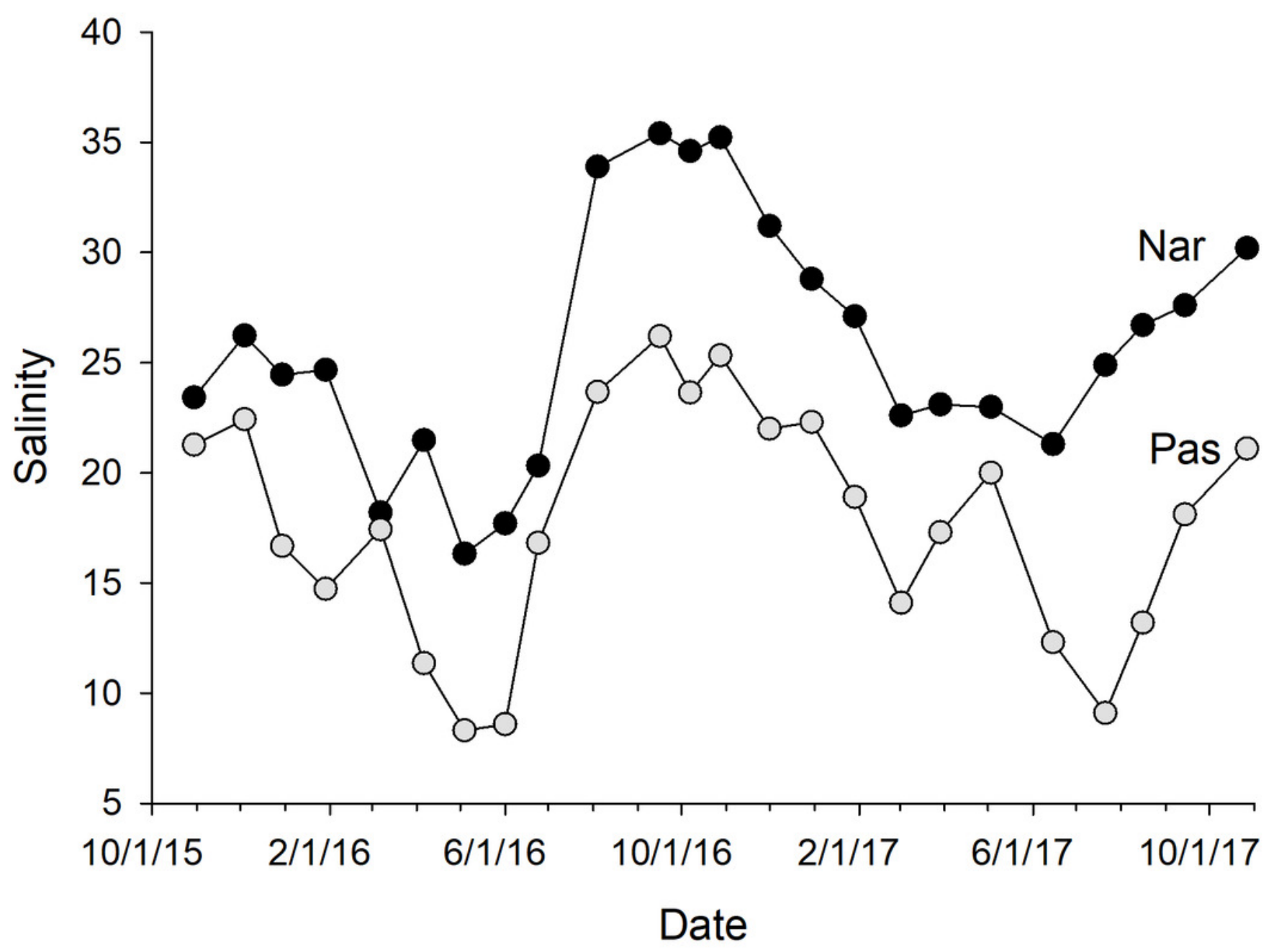

